\title{
IMPLEMENTASI APLIKASI AKUNTANSI PADA UKM ADIRAKA DALAM PENGELOLAAN KEUANGAN
}

\author{
Ratih Pratiwi1), Uding Sastrawan2) \\ 1Sekolah Vokasi IPB \\ email: ratih031113@gmail.com \\ 2Sekolah Vokasi IPB \\ email: che2usastra@gmail.com
}

\begin{abstract}
UKM Adiraka Group merupakan usaha yang bergerak dalam bisnis furnitur. Masalah yang sering terjadi pada UKM Adiraka Group yaitu pencatatan transaksi secara manual membutuhkan waktu cukup lama dalam mendapatkan data atau informasi keuangan, bagian keuangan harus bekerja lagi untuk menyusun dan membuat laporan. Berdasarkan permasalahan yang ada, maka dibutuhkan aplikasi yang mampu mengatasi masalah waktu dan tenaga. Oleh karena itu perancangan aplikasi akuntansi berbasis web diperlukan sebagai media penunjang sistem keuangan. Data yang dirancang akan diproses menggunakan PHP Hypertext Preprocessor ke dalam tabel, kueri, dan laporan. Pemilik dan departemen keuangan dapat membuat keputusan lebih cepat dan lebih mudah menggunakan aplikasi ini.
\end{abstract}

Keywords: Accounting, Information System, Inventory, Manual

\section{PENDAHULUAN}

Perkembangan teknologi informasi yang semakin pesat, membawa dampak yang cukup besar dalam berbagai bidang khususnya dalam bisnis. Sistem informasi yang terintegrasi dan komputerisasi diperlukan bagi Pengusaha untuk memaksimalkan kinerja bisnis, mulai dari pengolahan data yang dilakukan secara manual sehingga diolah dan disajikan menjadi data yang terkomputerisasi. Selain informasi yang terintegrasi juga dapat memberikan informasi dengan cepat, akurat, relevan, lengkap dan tepat bagi pengusaha dalam menentukan langkah -langkah bisnis selanjutnya. Namun, penerapan teknologi informasi khususnya bidang keuangan pada Usaha Kecil Menengah (UKM) masih banyak ditemukan secara sederhana yaitu pencatatan keuangan secara manual.

Salah satu kendala utama yang sering dihadapi oleh pengusaha dalam menerapkan teknologi informasi pada bisnisnya adalah biaya pembuatan sistem informasi yang cukup mahal. Hal ini sangat dirasakan bagi para pelaku Usaha Kecil Menengah (UKM) yang sedang berupaya mengembangkan bisnisnya. Sehingga kegiatan UKM sangat sulit dalam menggunakan teknologi informasi secara terkomputerisasi dalam menjalankan dan mengembangkan usahanya, serta pengetahuan pelaku kegiatan UKM terhadap perkembangan teknologi informasi masih terbatas.

Sebagai pengusaha dengan semakin pesat perkembangan UKM saat ini dituntut untuk berfikir kreatif dan inovatif dalam menjalankan sebuah bisnis. Salah satu faktor agar UKM dapat berkembang dan memiliki daya saing yang kuat adalah dengan pengelolaan keuangan yang baik dan terkomputerisasi. Kondisi ini yang juga dialami salah satu UKM yaitu UKM Adiraka Group.

\section{ANALISIS SITUASI}

Masalah yang sering terjadi pada UKM Adiraka Group yaitu pencatatan transaksi secara manual membutuhkan waktu cukup lama dalam mendapatkan data atau informasi keuangan, bagian keuangan harus bekerja lagi untuk menyusun dan membuat laporan. Berdasarkan permasalahan yang ada, maka dibutuhkan aplikasi yang mampu mengatasi masalah waktu dan tenaga. Oleh karena itu perancangan aplikasi akuntansi berbasis web diperlukan sebagai media penunjang sistem keuangan.

Tujuan yang akan dicapai dalam penelitian ini adalah merancang aplikasi akuntansi menggunakan $P H P$ Hypertext Preprocessor dan MySQL pada UKM Adiraka Group 


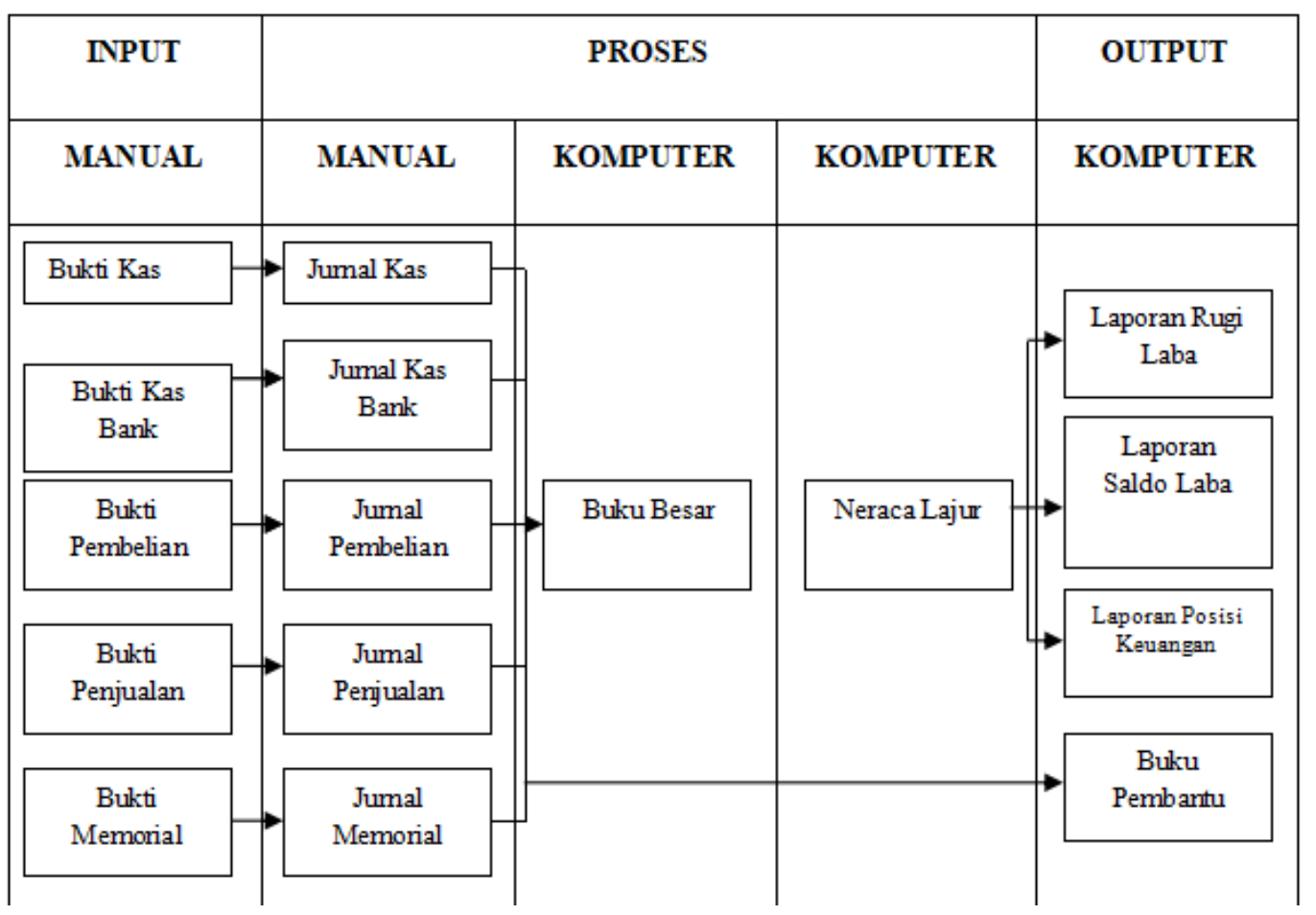

Gambar 1. Kerangka Pemikiran Penelitian

\section{METODE PENELITIAN}

\section{Kerangka Pemikiran}

Berdasarkan Gambar 1. Dijelaskan bahwa proses pengolahan data transaksi berdasarkan siklus akuntansi dimulai dari pencatatan transaksi ke jurnal, kemudian diposting ke Buku Besar dan ke Buku Pembantu, dari Buku Besar dipindahkan ke Neraca Lajur, kemudian dipindahkan menjadi Laporan Keuangan (Laba-Rugi, Laba Ditahan dan Laporan Posisi Keuangan)

\section{Jenis Data}

Perancangan aplikasi akuntansi berbasis web pada UKM Adiraka Group menggunakan PHP Hypertext Preprocessor dan MySQL. Jenis data yang digunakan penulis menggunakan data primer dan data sekunder.

\section{Metode Pengumpulan Data}

Pengumpulan data-data yang diperlukan dalam penelitian dilakukan dengan metode sebagai berikut: Riset Kepustakaan (Library research), Riset Lapangan (Field research). Pengumpulan data dilakukan dengan cara : Wawancara/Interview, Observasi dan Dokumentasi

\section{Tahap Pengembangan Sistem} Analisis Sistem
Penelitian ini dilaksanakan berdasarkan rencana yang telah disusun berdasarkan kerangka pemikiran penelitian. Adapun kerangka pemikiran penelitian lebih jelasnya dapat dilihat pada Gambar 1 Langkah-langkah dalam analisis sistem adalah :

1. Identifikasi masalah dan sumber masalah

2. Identifikasi kebutuhan informasi

3. Alternatif sistem yang dibutuhkan

\section{Alat Analisis}

Alat Analisis menggunakan PHP (Hypertext Preprocessor) dan MYSQL.

\section{Desain Sistem}

Tahap ini menyusun sistem baru dan menerangkannya secara tertulis. Kegiatan yang dilakukan adalah:

1. Permodelan sistem: Data flow diagram (DFD) Data flow diagram merupakan grafik yang dipresentasikan ke dalam arus melalui sistem.

2. Perancangan Database: Entity Realationship Diagram (ERD), Desain database, Desain input, Desain output

3. Implementasi Sistem

\section{ANALISIS DATA DAN PEMBAHASAN}

\section{Perancangan Sistem Aplikasi}

Perancangan menu dari aplikasi akuntansi berbasis web menggunakan PHP merupakan gambaran dari 
sistem yang akan dirancang dalam kegiatan siklus admin aplikasi akuntansi menggunakan PHP. akuntansi. Gambar 2 merupakan perancangan menu

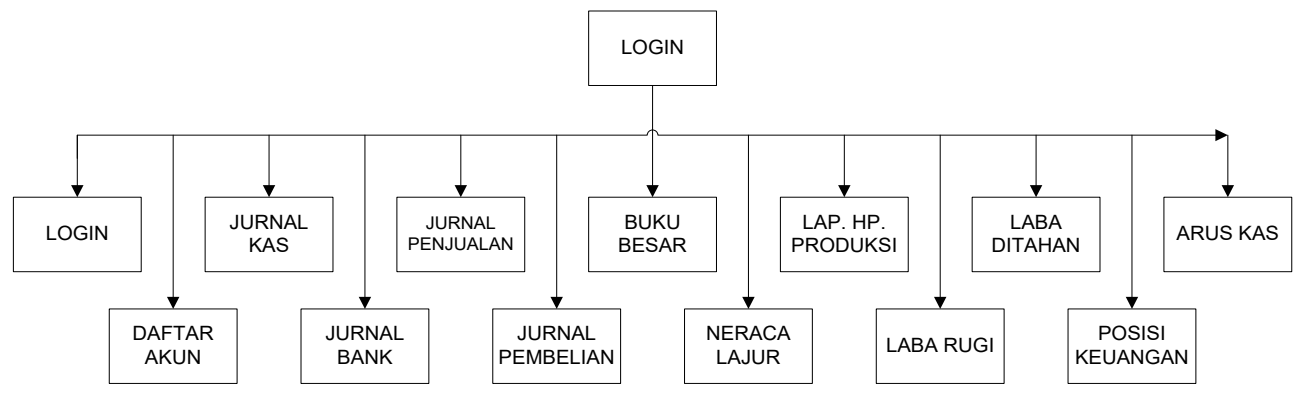

Gambar 2. Perancangan Menu Admin Akuntansi

Gambar 2 merupakan menu admin yang dirancang dan ditampilkan pada aplikasi akuntansi pada UKM Adiraka Group. Menu admin diatas adalah gambaran dari aplikasi yang dibuat menggunakan PHP untuk memudahkan admin dalam melakukan proses pencatatan keuangan.

\section{Mengimplementasikan Rancangan Aplikasi}

Implementasi rancangan aplikasi akuntansi adalah realisasi dari proses perancangan yang dilakukan pada tahap perancangan sebelumnya. Pada bagian ini dijelaskan implementasi rancangan yang disertai dengan beberapa kode program.

\section{Antarmuka Login}

Halaman antarmuka login merupakan halaman bagi user utuk masuk ke halaman utama. Pada halaman ini user akan diminta untuk memasukkan username, password, level dan tombol login yang sudah diberi hak untuk dapat mengakses server database. Apabila yang login bukan user atau yang diberi hak untuk mengakses server ini, maka halaman utama tidak akan terbuka. Jadi server ini hanya bisa diakses oleh pihak Adiraka Group yang terdaftar pada server ini dan antarmuka ini bersifat rahasia. Tampilan implementasi antaramuka login dapat dilihat pada Gambar 3:

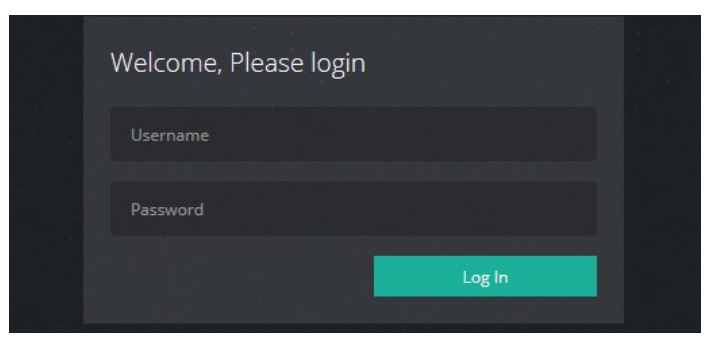

Gambar 3. Tampilan Halaman Login

\section{Antarmuka Halaman Utama}

Pada halaman utama setiap user yang diberi hak untuk mengakses server ini akan melihat tampilan menu aplikasi akuntansi yang dapat digunakan untuk menginput transaksi yang terjadi sesuai dengan menu yang dipilih.

Tampilan implementasi halaman utama jika yang login sebagai admin dapat dilihat pada Gambar 3

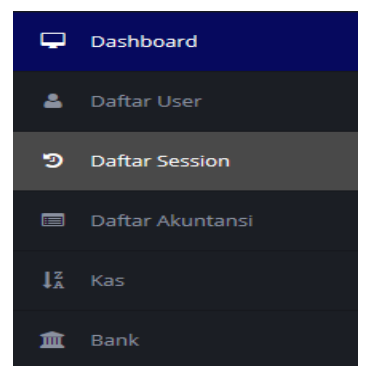

Gambar 3. Tampilan Halaman Utama Admin 
Halaman utama admin tampil apabila yang mengakses halaman ini adalah sebagai admin, semua menu pada halaman ini akan disajikan seperti daftar user, daftar session, daftar akuntansi, jurnal kas, jurnal bank, jurnal pembelian, jurnal penjualan, jurnal memorial, buku besar, neraca lajur, laporan harga pokok produksi laporan rugi laba, laporan saldo laba, dan laporan posisi keuangan. Admin dapat melihat data pada semua menu tersebut.

\section{Antarmuka Data User}

Pada halaman ini user dapat melihat data-data user yang dapat mengakses aplikasi ini. Antaramuka data user digunakan untuk menginputkan pengguna yang dapat login ke halaman ini.

Tampilan implementasi halaman data user dapat dilihat pada Gambar 4:

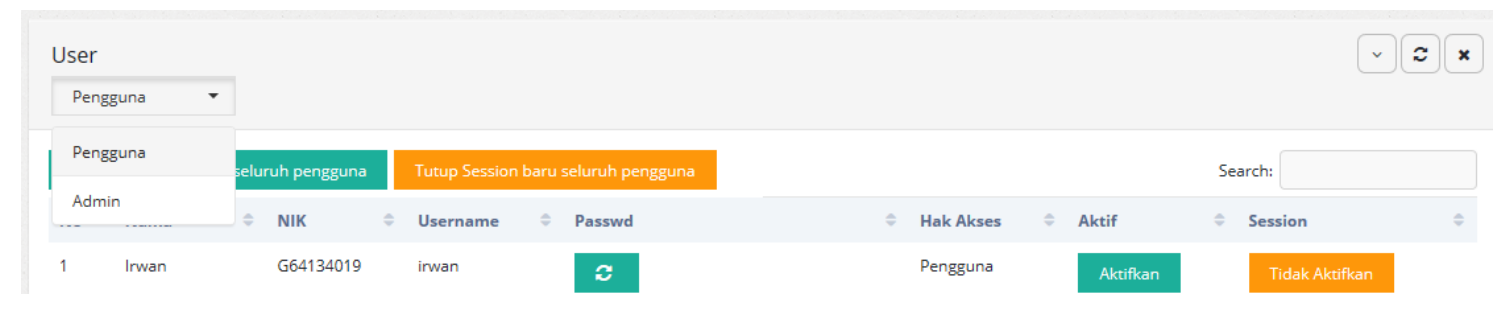

Gambar 4. Tampilan Halaman Data User

Gambar 4 adalah output dari penginputan yang sudah dilakukan pada gambar 5, yang selanjutnya akan diproses untuk menghasilkan laporan data user. Pada gambar 4 dapat dilihat user yang bisa mengakses aplikasi ini terdiri dari dua level yaitu Bagian Keuangan Adiraka Group sebagai pengguna dan Manajer sebagai admin. Kode sandi setiap user berbeda-beda. Sedangkan tampilan Add data user dapat dilihat pada Gambar 5:

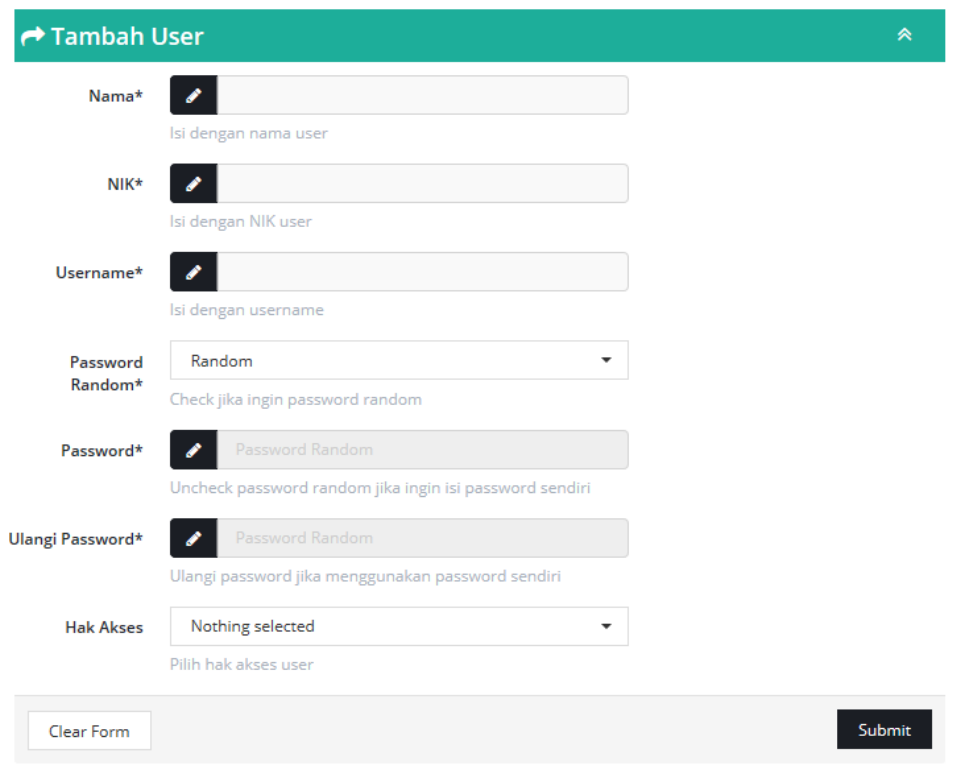

Gambar 5. Tampilan Halaman Add Data User

Pada halaman ini user dapat menginputkan data user dengan memasukkan kode yang langsung otomatis terisi sendirinya, masukkan nama lengkap, nik, username, password dan hak akses sesuai dengan data yang dibutuhkan. Dan tombol submit untuk menyimpan data yang sudah di input. Dengan klik submit maka data yang sudah di input akan tampil seperti pada Gambar 5. Sedangkan operasi clear form untuk menghapus data user tersebut.

\section{Antarmuka Daftar Akun}

Pada halaman daftar akun dapat melihat sejumla nomor akun dan nama akun dari perkiraan akuntansi. 
Tampilan implementasi daftar akun dapat dilihat pada Gambar 6:

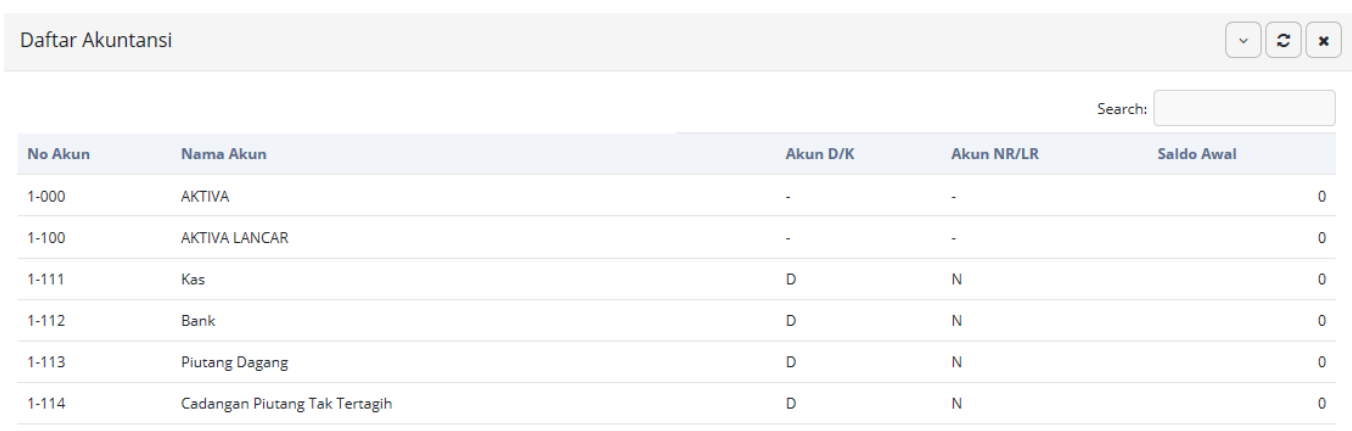

Gambar 6. Tampilan Halaman Daftar Akun

Pada gambar 6 user dapat melakukan penginputan nama akun, akun $\mathrm{D} / \mathrm{K}$, akun $\mathrm{NR} / \mathrm{LR}$, dan saldo awal. Kemudian klik simpan saldo awal. Nilai saldo awal akan tersimpan otomatis pada saldo awal di Buku Besar.

\section{Antarmuka Jurnal Kas}

Pada halaman antarmuka jurnal kas digunakan untuk mencatat transaksi keuangan perusahaan yang terkait dengan penerimaan dan pengeluaran kas. Tampilan implementasi jurnal kas dapat dilihat pada Gambar 7:

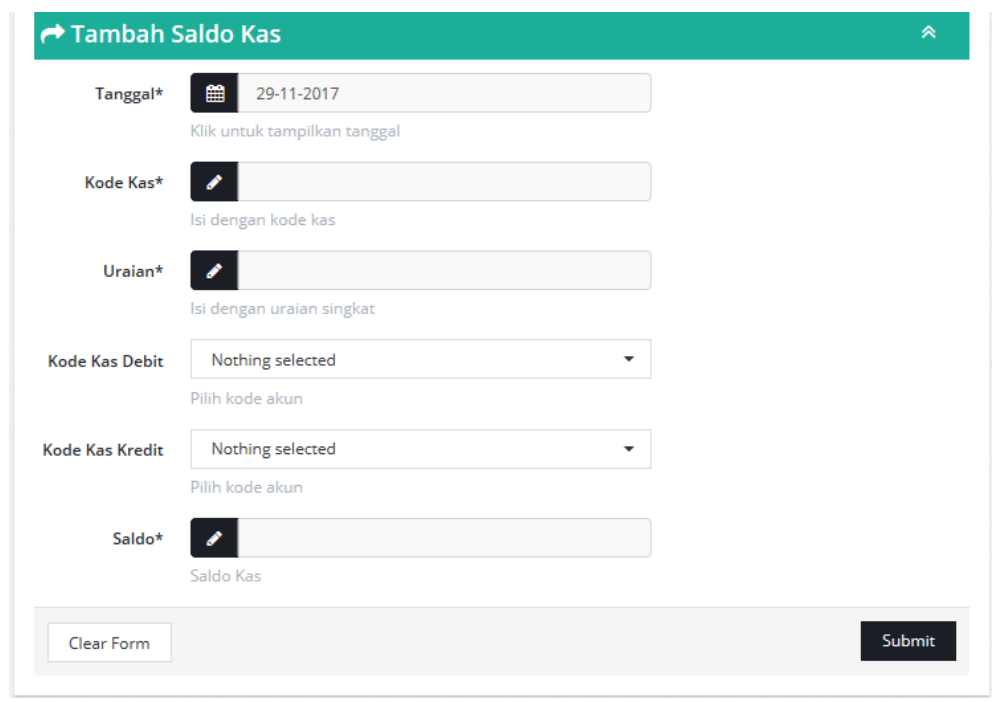

Gambar 7. Tampilan Tambah Saldo Kas

Tampilan jurnal kas terdiri atas : Tanggal,Kode kas, Uraian, Kode Kas Debit/Kode Kas Kredit, Saldo, Clear Form dan tombol submit untuk menyimpan data yang sudah di input. Dengan klik submit maka data yang sudah di input akan tampil seperti pada gambar 8 .

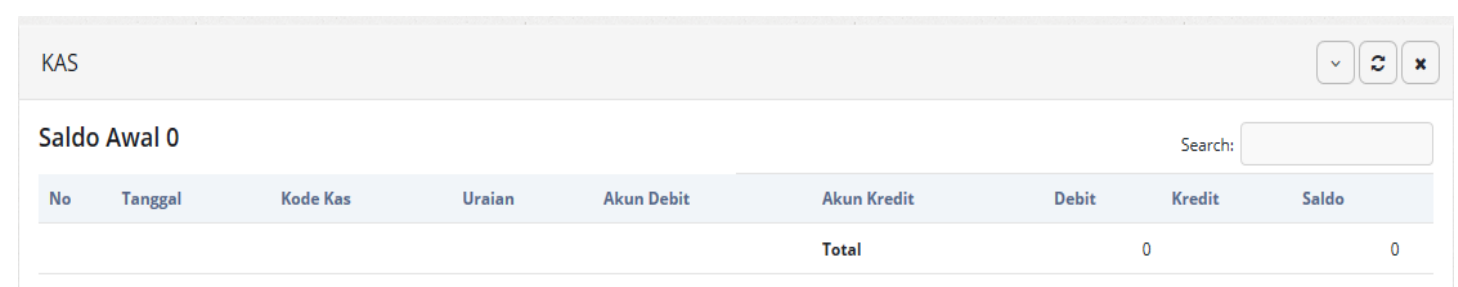

Gambar 8. Tampilan Jurnal Kas 
Antarmuka Jurnal Bank

Pada halaman antarmuka jurnal kas digunakan untuk mencatat transaksi keuangan perusahaan yang terkait dengan penerimaan dan pengeluaran bank. Tampilan implementasi jurnal kas dapat dilihat pada Gambar 9:

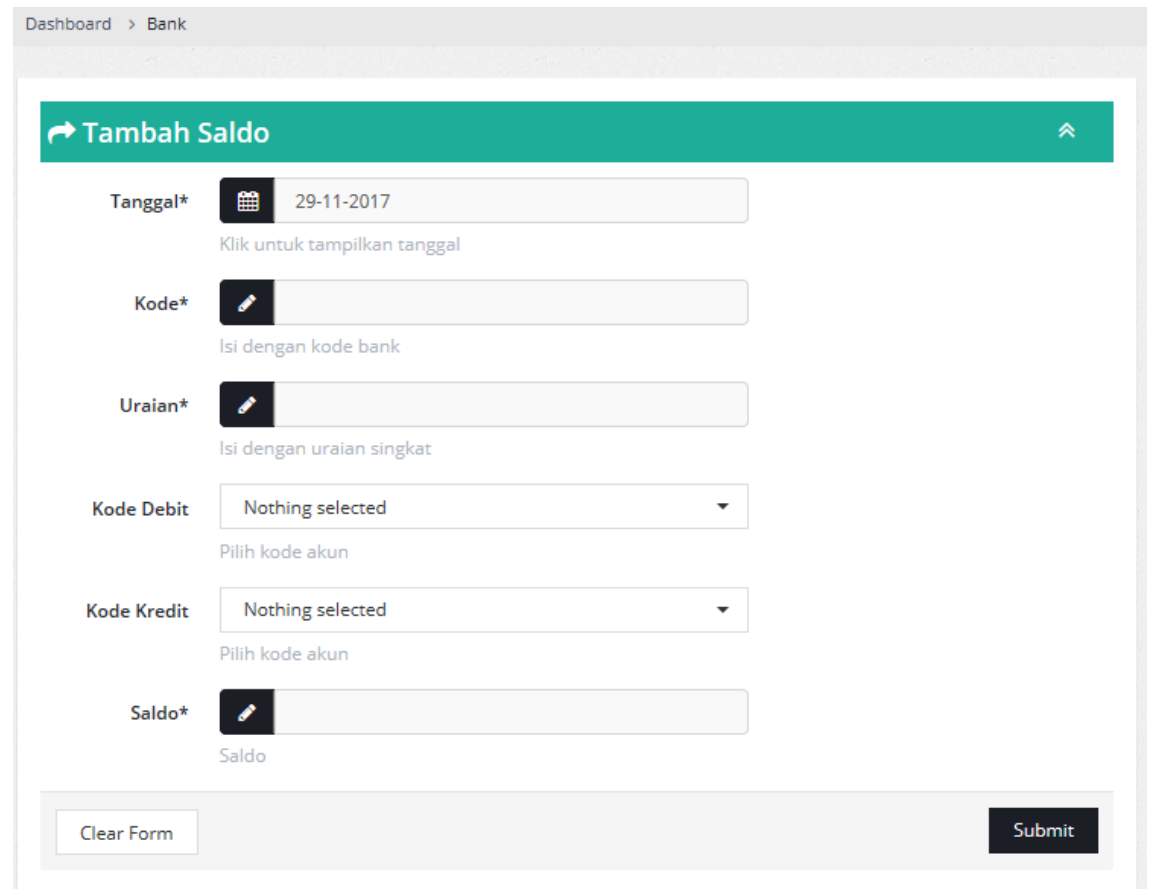

Gambar 9. Tampilan Tambah Saldo Bank

Tampilan jurnal bank terdiri atas: Tanggal, Kode, menyimpan data yang sudah di input. Dengan klik Uraian, Kode Debit/Kode Kredit, Saldo, Clear Form, submit maka data yang sudah di input akan tampil untuk menghapus transaksi dan tombol submit untuk

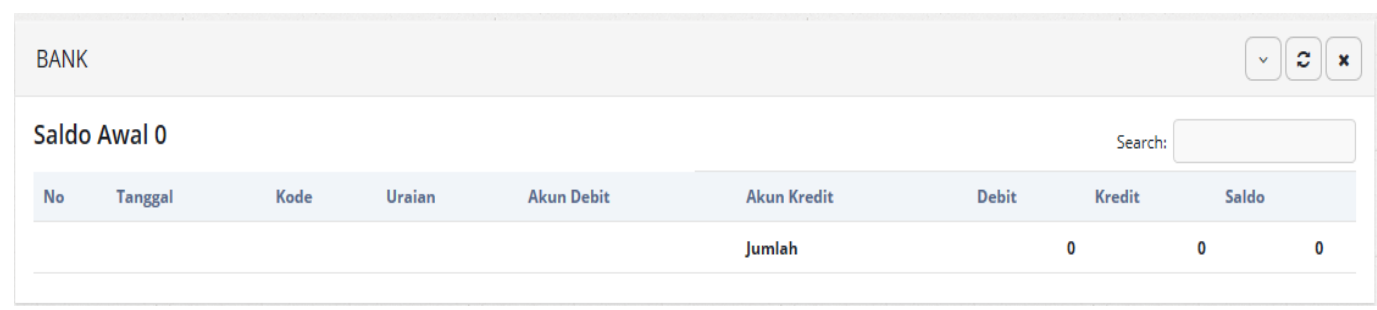

Gambar 10. Jurnal Bank

\section{Antarmuka Jurnal Pembelian}

Pada halaman antarmuka jurnal kas digunakan untuk mencatat transaksi keuangan perusahaan yang terkait dengan pembelian. Tampilan implementasi jurnal pembelian dapat dilihat pada Gambar 11: 


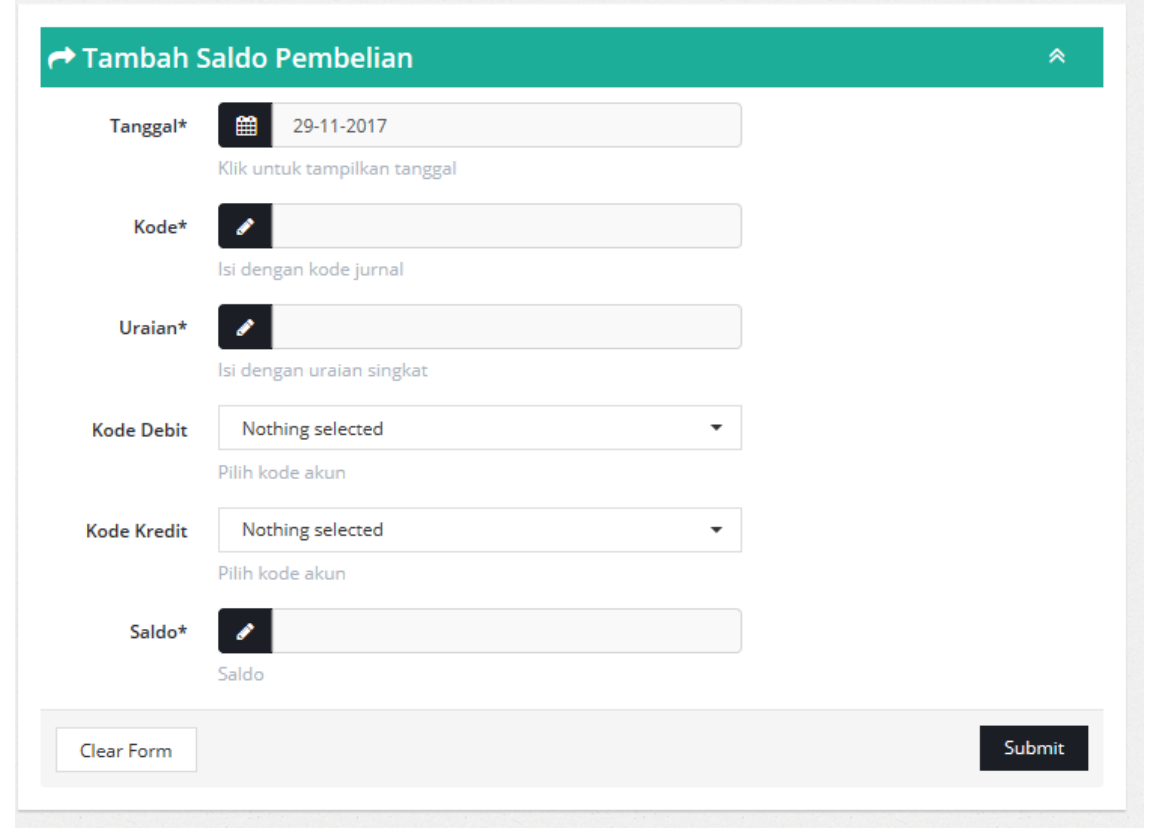

Gambar 11. Tampilan Tambah Saldo Pembelian

Tampilan jurnal kas terdiri atas: Tanggal, Kode, Uraian, Nilai PPN Masukan secara otomatis muncul ketika Kode Debit/Kode Kredit, Saldo,Clear Form, untuk menginput nilai pembelian. menghapus transaksi dan tombol submit untuk menyimpan data yang sudah di input. Dengan klik submit maka data yang sudah di input akan tampil seperti pada Gambar 12.

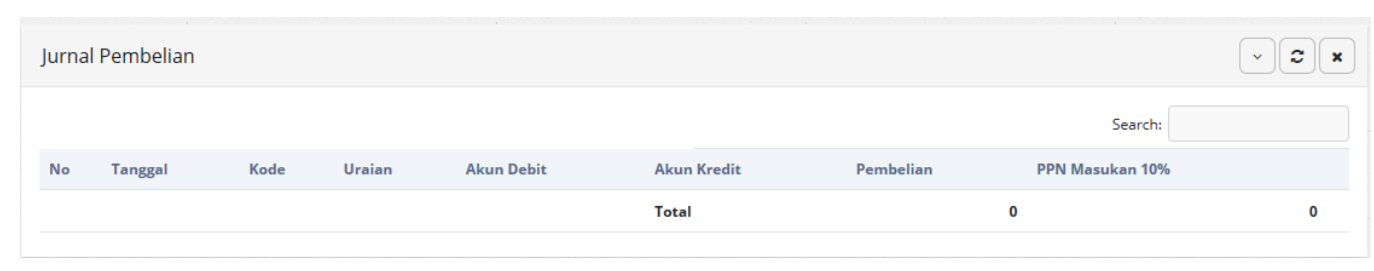

Gambar 12. Jurnal Pembelian

\section{Antarmuka Jurnal Penjualan}

Pada halaman antarmuka jurnal kas digunakan untuk mencatat transaksi keuangan perusahaan yang terkait dengan penjualan. Tampilan implementasi jurnal penjualan dapat dilihat pada Gambar 13: 


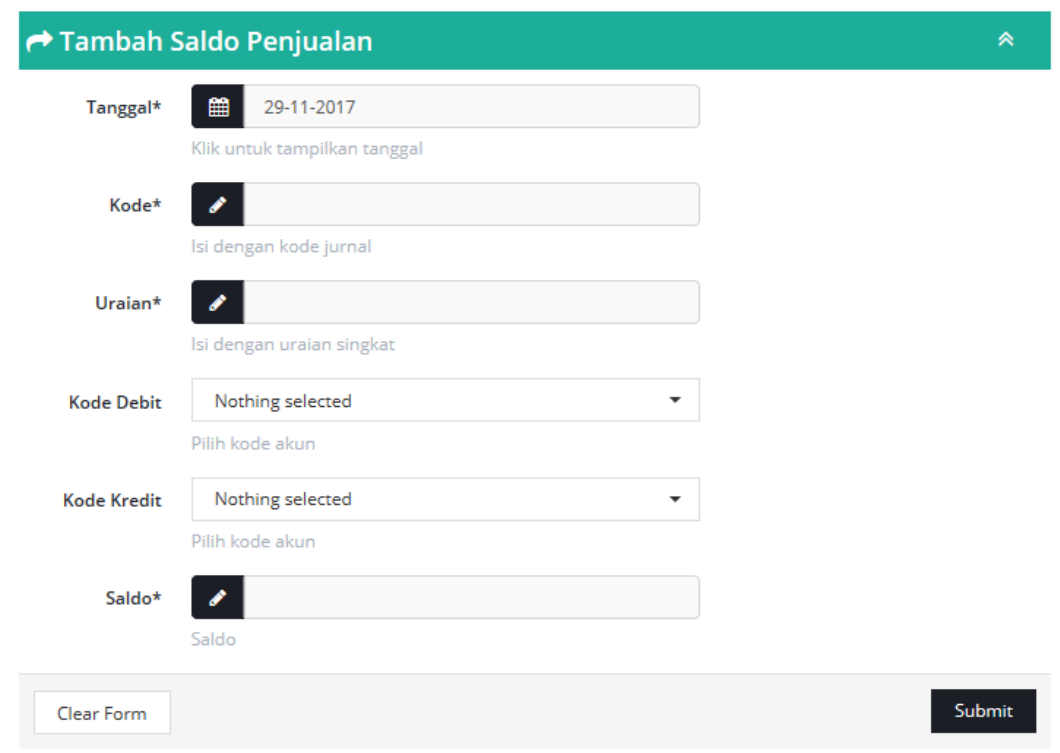

Gambar 13. Tampilan Tambah Saldo Penjualan

Tampilan jurnal penjualan terdiri atas: Tanggal,Kode, menyimpan data yang sudah di input. Dengan klik Uraian, Kode Debit/Kode Kredit, Saldo, Clear Form, submit maka data yang sudah di input akan tampil untuk menghapus transaksi dan tombol submit untuk seperti pada Gambar 14.

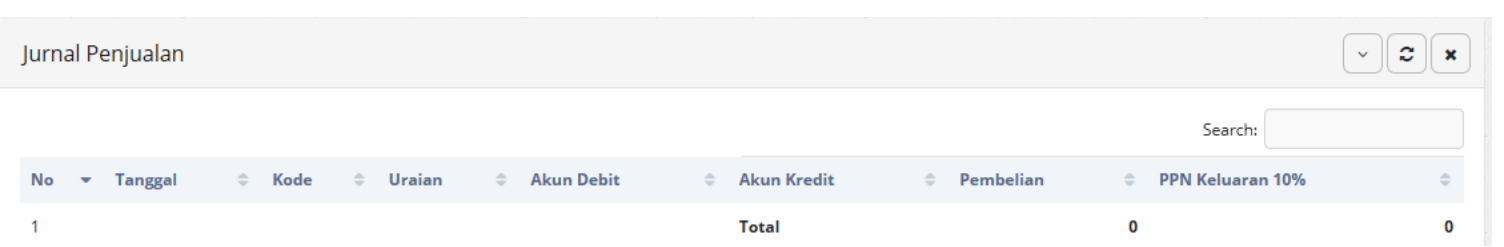

Gambar 14. Jurnal Penjualan

Nilai PPN Keluaran secara otomatis muncul ketika menginput nilai penjualan

\section{Antarmuka Jurnal Memorial}

Jurnal memorial merupakan penyesuaian yang dibuat dari data-data memorial, diantaranya biaya kerugian piutang tak tertagih, biaya sewa dibayar dimuka, biaya asuransi dibayar di muka, biaya penyusutan aktiva tetap dan lainnya. Tampilan implementasi jurnal memorial dapat dilihat pada Gambar 15: 


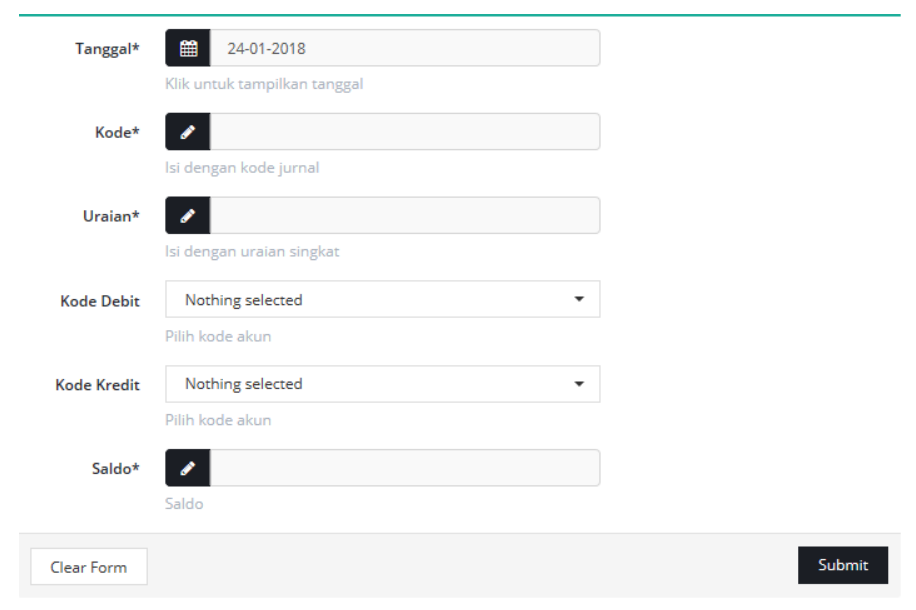

Gambar 15. Tampilan Tambah Jurnal Memorial

Tampilan jurnal memorial terdiri atas: Tanggal,Kode, Uraian, Akun Debit/Akun Kredit, Debit, Kredit dan tombol submit untuk menyimpan data yang sudah di input. Dengan klik submit maka data yang sudah di input akan tampil seperti pada Gambar 16.

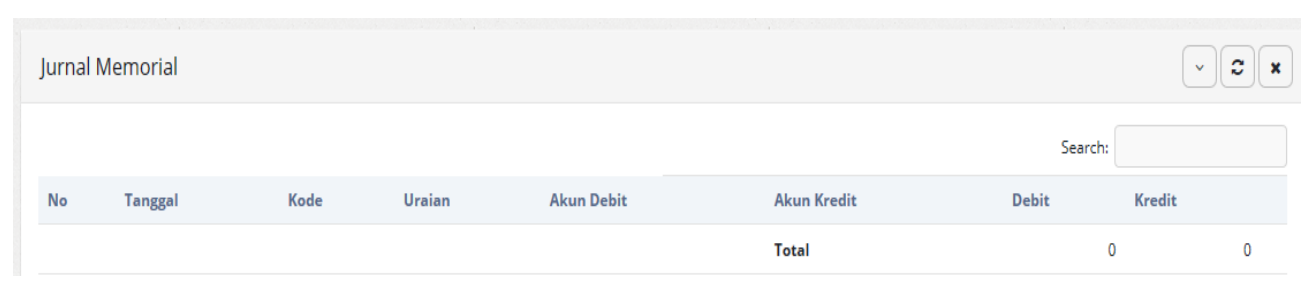

Gambar 16. Jurnal Memorial

Ketika semua transaksi sudah di posting pada jurnal, maka secara otomatis akan masuk ke dalam buku besar pada sel-sel di kolom Debit atau Kredit sesuai dengan akun masing-masing. Sedangkan kolom sumber jurnal menunjukkan informasi sumber jurnal dari jurnal mana posting tersebut berasal.

\section{Antarmuka Buku Besar}

Buku Besar ini dirancang berupa suatu ringkasan Buku Besar atau Summary General Ledger yang menggambarkan hasil posting yang diklasifikasikan dan diakumulasikan dari beberapa sumber jurnal ke dalam Buku Besar. Tampilan implementasi buku besar dapat dilihat pada Gambar 17:

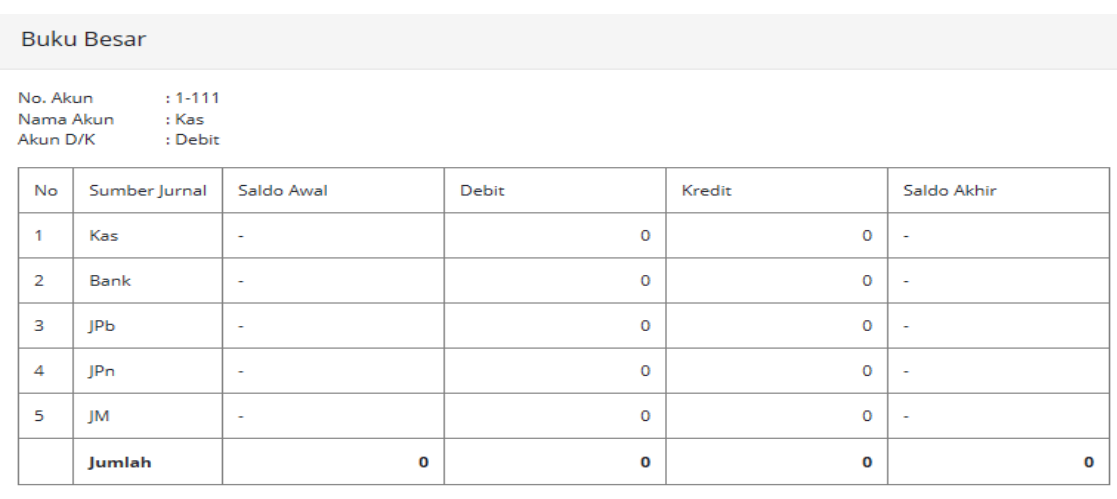

Gambar 17. Tampilan Buku Besar 
Tampilan buku besar terdiri atas: Saldo awal, Debit, Kredit, Saldo akhir Buku Besar

\section{Antarmuka Neraca Lajur}

Neraca lajur merupakan hasil pemindahan yang didapat dari saldo akhir buku besar untuk dipilah ke dalam saldo Akun Laba Rugi dan Laporan Posisi
Keuangan. Tampilan implementasi neraca lajur dapat dilihat pada Gambar 18:

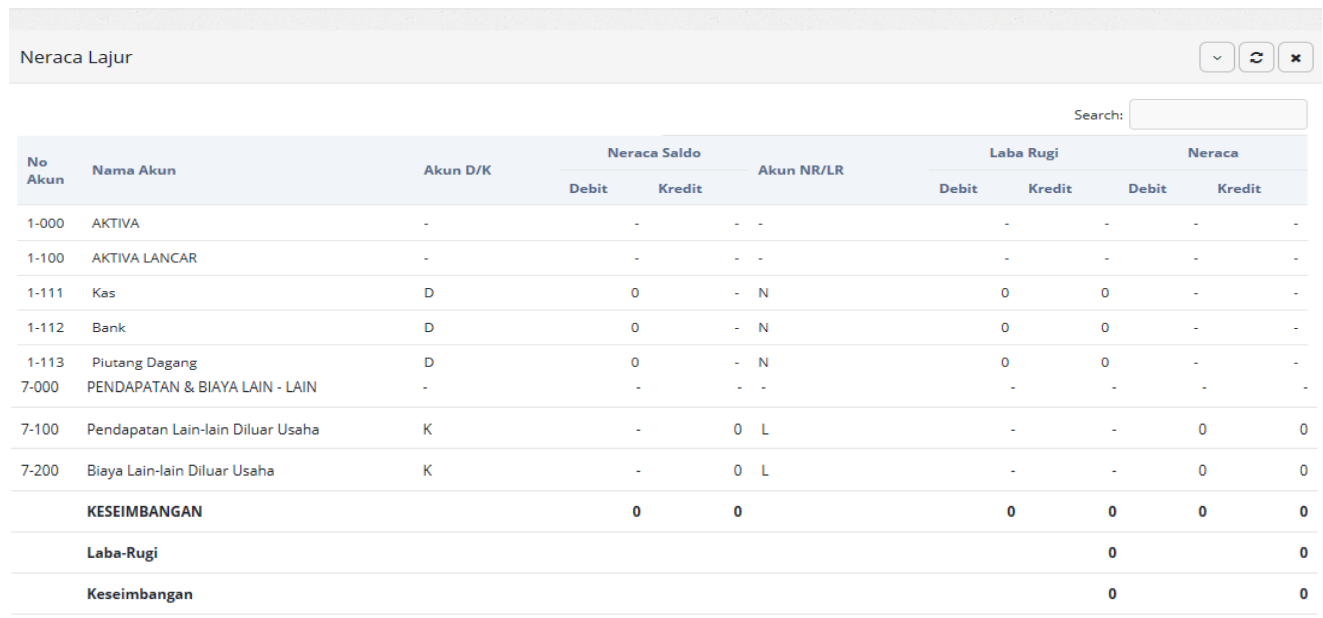

Gambar 18. Tampilan Neraca Lajur

Tampilan neraca lajur terdiri atas: Akun D/K, Neraca Saldo Debit,Neraca Saldo Kredit.Akun NR/LR, LabaRugi Debit,.Laba-Rugi Kredit, Neraca Debit, Neraca Kredit.

\section{Antarmuka Laporan Harga Pokok Produksi}

Laporan ini terdiri dari seluruh biaya yang dipergunakan untuk menghasilkan suatu produk dan kemudian dibebankan pada produk tersebut, yang terdiri atas biaya bahan baku, tenaga kerja dan overhead pabrik.

Tampilan implementasi laporan harga pokok produksi dapat dilihat pada Gambar 19:

Harga Pokok Produksi
\begin{tabular}{|l|l|}
\hline $\begin{array}{l}\text { No } \\
\text { Akun }\end{array}$ & Nama Akun \\
\hline $5-100$ & Pemakaian Bahan Baku \\
\hline $5-200$ & Tenaga Kerja Langsung \\
\hline $5-300$ & Biaya Overhead Pabrik \\
\hline & Jumlah Beban Produksi \\
\hline $5-400$ & Persediaan Awal Barang dalam Proses \\
\hline & Jumlah Barang dalam Proses \\
\hline $5-500$ & Persediaan Akhir Barang dalam Proses \\
\hline & Harga Pokok Produksi \\
\hline
\end{tabular}

Gambar 19. Laporan Harga Pokok Produksi

\subsubsection{Antarmuka Laporan Laba Rugi}

Laporan ini berfungsi membantu manajemen mengetahui apakah bisnis berada dalam posisi laba/rugi, apabila pendapatan lebih besar daripada beban, maka bisnis memperoleh laba, sebaliknya jika pendapatan cenderung lebih kecil daripada beban, maka kemungkinan besar mengalami kerugian. 
Tampilan implementasi laporan laba rugi dapat dilihat pada Gambar 20:

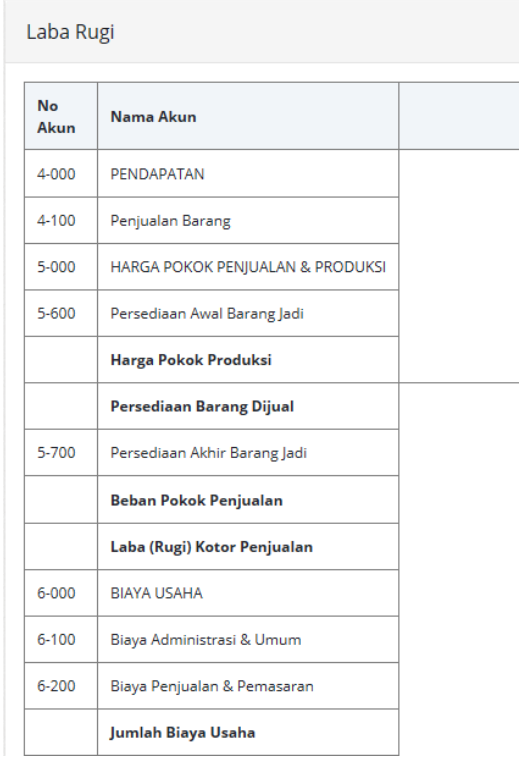

Gambar 20. Laporan Laba Rugi

\subsubsection{Antarmuka Laporan Laba Ditahan}

Tampilan implementasi laporan laba ditahan dapat dilihat pada Gambar 21

Laba Ditahan

\begin{tabular}{|l|l|l}
\hline $\begin{array}{l}\text { No } \\
\text { Akun }\end{array}$ & Nama Akun & \\
\hline $3-200$ & Laba Ditahan & \\
\hline & Laba (Rugi) Periode Berjalan & \\
\hline & Jumlah Laba Ditahan & \\
\hline
\end{tabular}

Gambar 21. Laporan Laba Ditahan

\subsubsection{Antarmuka Laporan Posisi Keuangan} Jenis laporan keuangan ini menyajikan akun-akun aktiva, kewajiban dan ekuitas dalam satu periode
Tampilan implementasi laporan posisi keuangan dapat dilihat pada Gambar 22 

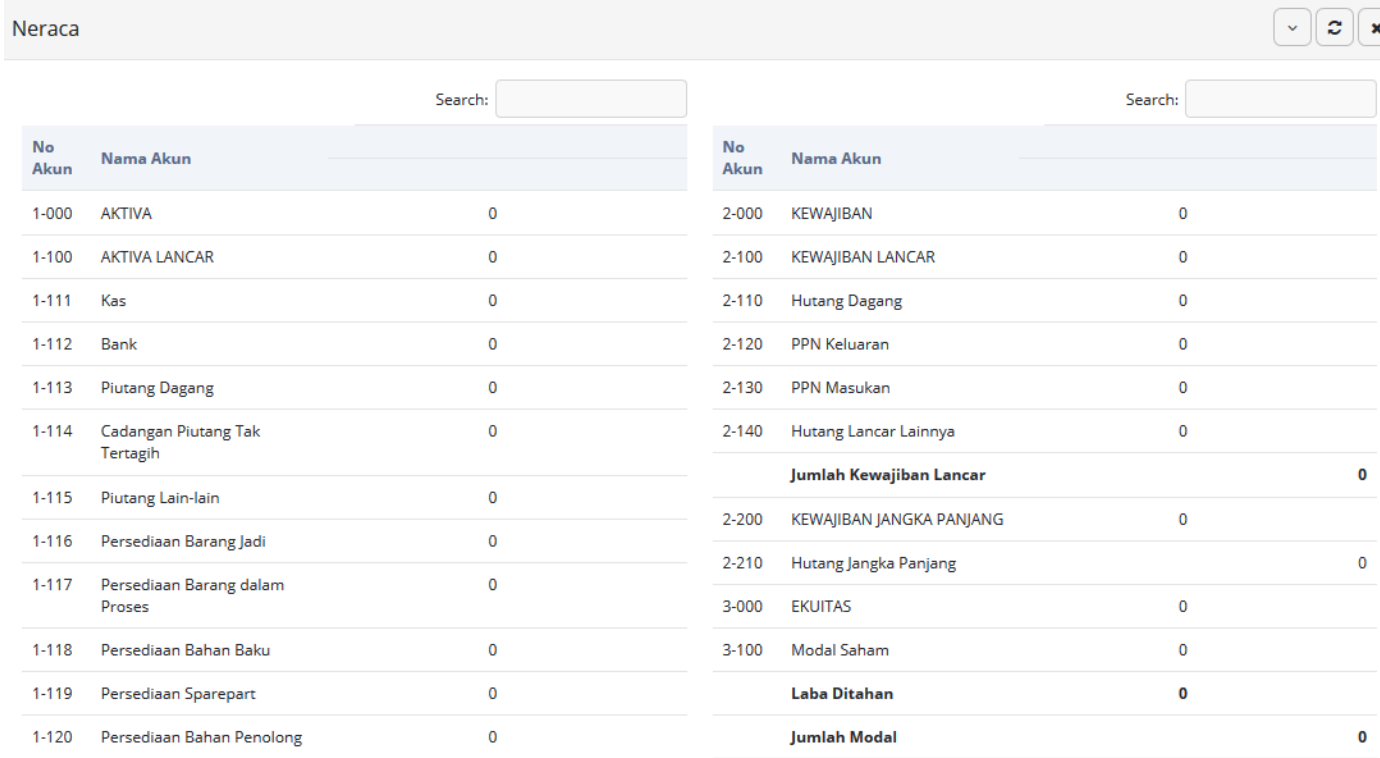

Gambar 22. Laporan Posisi Keuangan

\subsubsection{Antarmuka Laporan Arus Kas}

Jenis laporan keuangan ini untuk mengetahui perputaran arus dana yang berada di perusahaan, kemana dana atas kas pergi dan dari mana kas masuk. Hal ini supaya dapat mengontrol dana/kas perusahaan yang dimiliki selama ini.

Laporan arus kas dapat dilihat dari beberapa sumber yaitu hasil dari kegiatan operasional dan kas yang diperoleh dari pendanaan/pinjaman, sedangkan arus kas keluar dapat dilihat dari berapa banyak beban biaya yang dikeluarkan perusahaan baik untuk kegiatan operasional/investasi pada bisnis lain

Tampilan implementasi laporan arus kas dapat dilihat pada Gambar 23

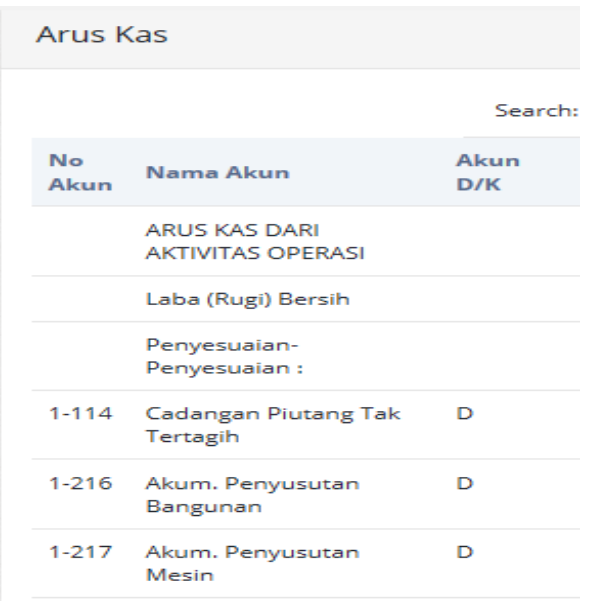

Gambar 23. Laporan Arus Kas

\section{KESIMPULAN, IMPLIKASI, KETERBATASAN DAN SARAN}

Berdasarkan hasil dari proses perancangan sampai dengan implementasi pada sistem aplikasi akuntansi menggunakan PHP dan MySQL pada UKM Adiraka Group, alur pencatatan transaksi secara komputerisasi terdiri dari form, tabel, query, dan output dari data yang sudah di input dan di proses menghasilkan report. Laporan yang dihasilkan adalah laporan harga pokok produksi, laporan laba rugi, laporan laba ditahan, laporan posisi keuangan dan arus kas. Keterbatasan dalam pembuatan aplikasi ini adalah mengasumsikan pencatatan transaksi jurnal pembelian dan penjualan 
secara kredit, serta belum menambahkan fasilitas unduh atau cetak hasil laporan.

\section{DAFTAR RUJUKAN}

Abdullah T, Tantri F. 2016. Manajemen Pemasaran. Depok (ID): PT Raja Grafindo Persada.

Mulyadi. 2016. Sistem Akuntansi, Edisi Ketiga, Cetakan Keempat. Jakarta (ID): Salemba Empat.

Nugroho B. 2013. Membuat Aplikasi WEB Penjualan Pembelian dengan PHP, MySQL dan Dreamweaver. Yogyakarta (ID) : Alif Media.

Nugroho W. 2014. Sistem Informasi Akuntansi. Jakarta (ID): Erlangga.

Pratama AE. 2014. Sistem Informasi dan Implementasinya. Bandung (ID): Informatika Bandung.

Ristono A. 2013. Manajemen persediaan edisi satu. Yogyakarta (ID): Graha Ilmu.

Romney MB, Steinbart PJ. 2012. Sistem Informasi Akuntansi. Jakarta (ID): Salemba Empat.

Stice, Skousen. 2012. Akuntansi Intermediate, Edisi Kesembilan Belas, Buku Satu. Jakarta (ID): Salemba Empat.

Sujarweni VW. 2016. Sistem Akuntansi. Yogyakarta (ID): Pustaka Baru Press.

Susanto A. 2013. Sistem Informasi Akuntansi. Bandung (ID): Lingga Jaya.

Ratih Pratiwi, SE, M.Ak merupakan lulusan Magister Akuntansi pada Program Pasca Sarjana Universitas Pancasila pada tahun 2015. Saat ini sedang mengikuti Program Pendidikan Akuntansi di PERBANAS Jakarta.

Dia merupakan staf pengajar di Sekolah Vokasi Institut Pertanian Bogor sejak 2007. Pendidikan terakhir adalah Magister Sains Ilmu Manajemen di IPB lulus tahun 2014. Berpengalaman mengajar Manajemen Keuangan, Komputer Aplikasi Akuntansi, Lembaga Keuangan Agribisnis dan Ekonomi. 